\title{
Multidisciplinary approach to assess the water self-depuration characteristics of Suquía River (Córdoba, Argentina)
}

\author{
Carolina Merlo* and Adriana Abril
}

\begin{abstract}
Background: We analyzed the following characteristics of water self-depuration capacity along a polluted river (Suquía River) in Argentina: (a) abundance of microbial metabolic groups, (b) cover and type of vegetation, and (c) type and concentration of soil and sediment humic substances. The objective was to establish the modifications of water self-depuration characteristics of the polluted sites in comparison to a reference site in order to provide basic data for ecological restoration programs. Five samples of riparian soil, water, and sediments were collected at a reference site and five polluted sites during low- and high-flow water periods. In each site the vegetation type and soil cover were recorded. In all samples the abundance of ammonifiers, nitrate reducers, sulfate reducers, cellulolytic microorganisms, aerobic heterotrophs, and fermenters was measured. Besides, soil and sediment organic matter and humic and fulvic acids content were analyzed.
\end{abstract}

Results: Our results showed that all sites differed in their water self-depuration characteristics with respect to the reference site and that these variations are due to a combination of natural and anthropic factors. The Suquía River presents a great heterogeneity of water self-depuration characteristics but it does not achieve a mitigation of the anthropogenic impact produced by Córdoba city.

Conclusions: We concluded that restoration actions in lotic ecosystems should be adapted for each river sector.

Keywords: Humic substances; Microbial groups; Sediments; Sulfate reducer; Vegetation type

\section{Background}

River pollution is a global concern; therefore, river restoration programs are common in many countries. The aim of ecological restoration programs is to improve water quality, enhance in-stream habitat, and manage the riparian zone (Parkyn et al. 2003; Kang and Lin 2009; Gift et al. 2010). However, many river restoration programs fail to achieve their objectives partly because of a poor understanding of river system dynamics (Parkyn et al. 2003).

The key aspect of the river dynamics regarding the success of restoration programs is the degree of water selfdepuration, which allows the establishment of the magnitude of treatment effects in time and distance (Dzyuban 2003; Parkyn et al. 2003). Water self-depuration capacity in aquatic systems is based on the following characteristics: (a)

\footnotetext{
* Correspondence: cmerlo@agro.unc.edu.ar

Microbiología Agrícola, Facultad de Ciencias Agropecuarias, Universidad

Nacional de Cordoba, Av. Valparaiso s/n. Ciudad Universitaria, cc 509,

Córdoba, CP 5000, Argentina
}

the degradation of organic compounds by microbial activity (Nishihama et al. 2008), (b) the adsorption of xenobiotics and heavy metals in riparian soils and sediments (Hunter et al. 2009), and (c) the nutrients uptake by riparian vegetation (McIntyre et al. 2009). Thus, a multidisciplinary approach is required to assess the water self-depuration dynamics. However, studies about the characteristics of water self-depuration that include perspectives from microbial and plant ecology and soil science are scarce.

From microbial ecology, it is known that in aquatic ecosystems the aerobic microorganisms predominate in surface water and degraded organic compounds of low molecular weight. On the other hand, in reduced sediments, anaerobic microorganisms degrade organic compounds of high molecular weight deposited by flocculation or precipitation (Wetzel 2001; Artigas et al. 2009). It is important to highlight that microbial anaerobic metabolism transforms organic and inorganic compounds to volatile compounds, removing $\mathrm{C}, \mathrm{N}$, and $\mathrm{S}$ from ecosys- 
tems (Leonov and Chicherina 2008; Groffman et al. 2009; Gift et al. 2010).

Due to the low primary productivity of rivers, the major input of organic matter is allochthonous (Artigas et al. 2009; Kochi et al. 2010). Accordingly, in undisturbed environments the main sources of organic compounds are cellulose and lignin from riparian vegetation (Wallis et al. 2009). From soil science perspective, it is known that the degradation rate of these complex molecules under water-saturated conditions (anaerobic) is low, which favors the synthesis of humic substances (Wetzel 2001; Lopez et al. 2006). An important characteristic of the humic substances is the high capacity to retain xenobiotics in polluted sites (Calace et al. 2009).

The ecology of riparian vegetation is substantial for water self-depuration due to their great capacity to take up nutrients, thus avoiding eutrophication of the aquatic ecosystem (Wetzel 2001; Barton and Northup 2011). Accordingly, an initial step in restoration programs is the planting of riparian vegetation in the stream banks. Moreover, the riparian vegetation avoids bank erosion and improves the landscape aesthetic (Kang and Lin 2009). The mix of vegetation types (tree, shrubs, and grasses) is the best approach to reach the advantages mentioned above (Groffman et al. 2009).

The main factors that could modify the water selfdepuration characteristics have natural (climatic, geomorphologic, and hydrologic characteristics) and anthropogenic origin (urban discharges, channel modification, etc.) (Artigas et al. 2009; Carey and Migliaccio 2009; Kang and Lin 2009). Both natural and anthropic factors modify different aspects of lotic systems including nutrients, organic $\mathrm{C}$, and dissolved $\mathrm{O}_{2}$ contents (Carey and Migliaccio 2009), which affect microbial abundance and activity, altering natural depuration rate in time and distance (Dzyuban 2003; Kosolapov et al. 2003; Carey and Migliaccio 2009; Perryman et al. 2011).

Numerous authors have evaluated the pollution of Suquía River (Cordoba, Argentina) by means of different aspects such as (a) water and sediment heavy metal content, (b) air volatile organic compounds, (c) soil, water, and sediment chemical characteristics, and (d) soil, water, and sediment microbial indicators of sewage pollution (Pesce and Wunderlin 2000; Wunderlin et al. 2001; Contardo-Jara et al. 2009; Merlo et al. 2011; Monferrán et al. 2011; Pasquini et al. 2012). Besides, the effects of Suquía River pollution on aquatic biota, lichen, and vascular plant also have been assessed (Merlo et al. 2011; Maggioni et al. 2012). However, there are no basic data about the characteristics of water self-depuration from a multidisciplinary approach along Suquía River which allows to plan restoration activities. One of the key criteria of restoration programs is the identification of a reference site (minimally disturbed) as an optimal situation to be achieved in restoration process (Carey and Migliaccio 2009).

We hypothesized that the characteristics of water selfdepuration capacity in Suquía River are strongly modified by the pollution that is received from Cordoba city. To corroborate this hypothesis, we analyzed the characteristics of water self-depuration capacity in sectors of the river located at different distances from the pollution sources regarding to a reference site, based on the three characteristics mentioned above: (a) abundance of microbial metabolic groups, (b) cover and type of vegetation, and (c) type and concentration of soil and sediment humic substances. It is pretended to establish the modifications of water self-depuration characteristics of polluted sites in comparison to a reference site in order to provide basic data necessary to plan and implement ecological restoration programs.

\section{Methods}

\section{Study area}

The Suquía River of Cordoba province (Argentina) begins at the San Roque Dam and flows mainly from west to east for about $200 \mathrm{~km}$ until Mar Chiquita Lake. The watershed is located in a semiarid region, with a mean annual rainfall between 700 and $900 \mathrm{~mm}$, concentrated from October to April. The mean air temperatures are $10^{\circ} \mathrm{C}$ in winter and $26^{\circ} \mathrm{C}$ in summer. The San Roque Dam is an artificial lake where recreational activities have promoted the urbanization of the lake shorelines and surroundings. Thirty kilometers downstream from the dam, the Suquía River enters to Córdoba city (1.29 million inhabitants). In the last 20 years, the city's population has almost doubled, and growing industrialization has increased the risk of having toxic effluents discharged into the river. Near the eastern edge of the city, the Suquía River receives the sewage discharge from the Municipal Waste Water Treatment Plant (WWTP) (trickling beds with anaerobic sludge digestion) (Merlo et al. 2011) (Figure 1).

The flow regime of the rivers that form Suquía River drainage network is exclusively pluvial in origin, with a marked seasonality of the flow due to the irregular distribution of rainfall throughout the year (Pasquini et al. 2012). Though there is not a systematic study, the river flow can be estimated from the water released by the San Roque Dam. The Suquía River has shown a high-flow period, from December to April, with an estimated flow greater than $15 \mathrm{~m}^{3} \mathrm{~s}^{-1}$; whereas during the dry season, from May to November, its average estimated flow is $2.7 \mathrm{~m}^{3} \mathrm{~s}^{-1}$.

Due to that the Suquía River belongs to a semiarid zone and that the San Roque Dam regulates its flow, it is a shallow river.

The main taxonomic group of phytoplankton in Suquía River is the Bacillariophycea class totalling 12 species. 


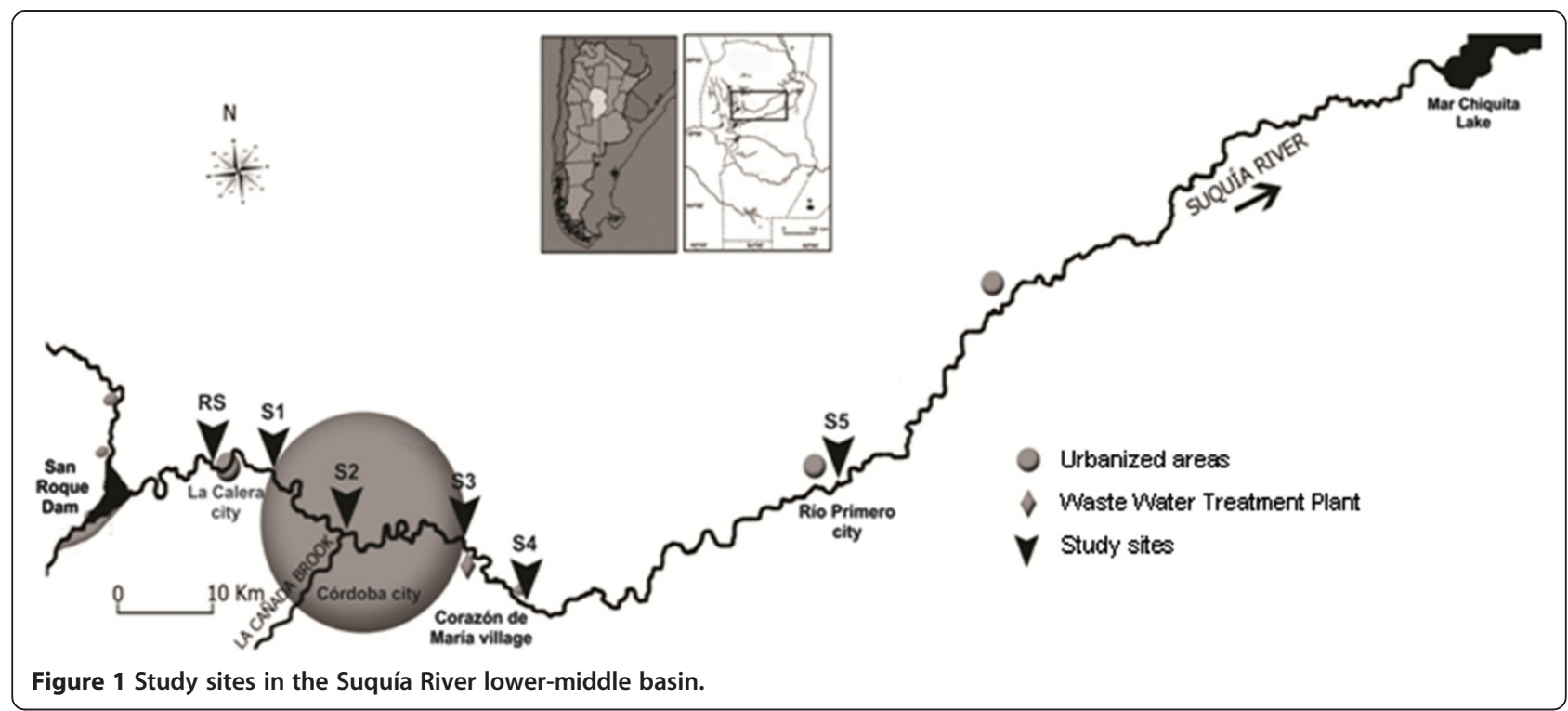

Also, some members of Desmidiaceae family and some cyanobacteria like Microcystis aeruginosa (Kützing) are represented (Daya 1987). Haro et al. (1986) mention that the amphibians Buffo arenarum (Hensel) and Leptodactylus ocellatus (Steffen) are common members of Suquía River, while Mangeaud (1998) found that more than the $90 \%$ of the invertebrate's species that inhabit the river are lost when it passes through the city. A systematized sampling along Suquía River detected 24 species of fish among permanent and occasional autochthons and introduced fishes (Haro et al. 1986). Recent studies showed that fish assemblage structure changed with increasing water quality degradation, showing a simpler structure at the most polluted area where few species found favorable conditions for their establishment in degraded zones (Merlo et al. 2011).

\section{Sampling design}

Six study sites were selected along Suquía River: La Calera city: reference site (RS), Córdoba city western border: site 1(S1), Córdoba city downtown: site 2 (S2), Córdoba city eastern border: site 3 (S3), Corazón de María village: site 4 (S4) and Río Primero city: site 5 (S5) (Table 1; Figure 1). There is not a pristine site; therefore, following Carey and Migliaccio (2009), a reference site with minimal conditions of pollution was selected. Moreover, RS allowed us to evaluate the modifications by the pollution received from Cordoba city since RS is located upstream of Cordoba city. The physical and chemical compositions of the same samples of Suquía River water, sediment, and riparian soil used in this study were published elsewhere (Merlo et al. 2011).

The study sites were sampled during low- and high-flow periods, August 2008 and March 2009, respectively. These months correspond with the minimum and maximum flow recorded by the Direction of Water and Sanitation of the Province of Córdoba. In both low- and high-flow periods, five replicate points were randomly selected at each study site along a 100-m linear transect on one shoreline, and in each point, one sample of each habitat (water, sediments, and riparian soil, 0 to $20 \mathrm{~cm}$ ) were collected in sterile receptacles. Water samples were taken 10 to $15 \mathrm{~cm}$ below the water surface in sterile glass bottles. Soil samples were collected from the top $20 \mathrm{~cm}$ in a sterile plastic bag. Finally, sediment samples were obtained from the first $10 \mathrm{~cm}$ of the top layer using a handle dredge. The sampling of all study sites at each flow period was done in the same day, and samples were immediately transported on ice to the laboratory and were processed within $24 \mathrm{~h}$ after collection. Soil and sediment samples were air-dried for $24 \mathrm{~h}$ and sieved through a $2-\mathrm{mm}$ mesh. All samples were stored at $4^{\circ} \mathrm{C}$ until analysis. During high-flow period, in each transect ( $5 \mathrm{~m}$ on each side), the vegetation structure was recorded and soil cover was estimated as the area of plant vertical projection (trees, shrubs, grasses, and forbs) on the soil (Feral et al. 2003).

\section{Analysis}

The ten samples of each site of both low- and high-flow periods were pooled in order to determine the following physical and chemical characteristics: (a) dissolved $\mathrm{O}_{2}$, $\mathrm{pH}$, and conductivity in water, using portable equipment (WTW, Multiline F/Set 3) and (b) percentage of sand, silt, and clay in soil and sediments (Table 2).

For each riparian soil and sediment sample, we measured total organic matter (OM) by the wet method of Walkley and Black (Nelson and Sommers 1996) and the humic substances content (HS) by alkali extraction $(\mathrm{NaOH})$. 
Table 1 Position and anthropic impact of Suquía River study sites

\begin{tabular}{|c|c|c|}
\hline River sites & Position & Anthropic impact \\
\hline RS, reference site (La Calera city) & $\begin{array}{l}18.4 \mathrm{~km} \text { downstream San Roque Dam, } 488 \mathrm{~m} \text { a.s.l., } \\
31^{\circ} 21^{\prime} 45^{\prime \prime} \mathrm{S} \text { and } 64^{\circ} 20^{\prime} 99^{\prime \prime} \mathrm{W}\end{array}$ & $\begin{array}{l}\text { Eutrophic waters from the San Roque } \\
\text { Dam and recreational use }\end{array}$ \\
\hline S1, site 1 (Córdoba city west border) & $\begin{array}{l}17.1 \mathrm{~km} \text { downstream } \mathrm{RS}, 417 \mathrm{~m} \text { a.s.l., } 31^{\circ} 23^{\prime} 07^{\prime \prime} \mathrm{S} \\
\text { and } 64^{\circ} 14^{\prime} 15^{\prime \prime} \mathrm{W}\end{array}$ & Sewage waters \\
\hline S2, site 2 (Córdoba city down town) & $\begin{array}{l}12.1 \mathrm{~km} \text { downstream S1, } 393 \mathrm{~m} \text { a.s.l., } 31^{\circ} 23^{\prime} 82^{\prime \prime} \mathrm{S} \\
\text { and } 64^{\circ} 14^{\prime} 62^{\prime \prime} \mathrm{W}\end{array}$ & $\begin{array}{l}\text { Industrial effluents, sewage waters, and } \\
\text { run-off from La Cañada creek }\end{array}$ \\
\hline S3, site 3 (Córdoba city east border) & $\begin{array}{l}11 \mathrm{~km} \text { downstream S2, } 0.36 \mathrm{~km} \text { upstream WWTP, } \\
365 \mathrm{~m} \text { a.s.l., } 31^{\circ} 24^{\prime} 34^{\prime \prime} \mathrm{S} \text { and } 64^{\circ} 10^{\prime} 66^{\prime \prime} \mathrm{W}\end{array}$ & $\begin{array}{l}\text { Sewage waters, sand mining, and trash } \\
\text { in river banks }\end{array}$ \\
\hline S4, site 4 (Corazón de María village) & $\begin{array}{l}12 \mathrm{~km} \text { downstream WWTP, } 341 \mathrm{~m} \text { a.s.l., } 31^{\circ} 26^{\prime} 81^{\prime \prime} \mathrm{S} \\
\text { and } 63^{\circ} 59^{\prime} 45^{\prime \prime} \mathrm{W}\end{array}$ & $\begin{array}{l}\text { Sewage waters from waste water treatment } \\
\text { plant (WWTP) }\end{array}$ \\
\hline S5, site 5 (Río Primero city) & $\begin{array}{l}51.1 \mathrm{~km} \text { downstream S4, } 243 \mathrm{~m} \text { a.s.l., } 31^{\circ} 20^{\prime} 29^{\prime \prime} \mathrm{S} \\
\text { and } 63^{\circ} 36^{\prime} 58^{\prime \prime} \mathrm{W}\end{array}$ & Agricultural area and recreational use \\
\hline
\end{tabular}

From the alkaline extract, the humic (HA) and fulvic acids (FA) were separate by acid precipitation $\left(\mathrm{H}_{2} \mathrm{SO}_{4}\right)$ (Marinari et al. 2010). Non-humic substances (NHS) were calculated as the difference between OM and HS (Abril et al. 2013).

In all samples the abundance of microbial metabolic groups were measured: (a) sulfate reducers, nitrate reducers, ammonifiers, and cellulolytics in specific liquid media by the most probable number technique and (b) total aerobic heterotrophs and fermenters in solid culture media by agar plate methods (Lorch et al. 1995).

One gram of sediment and riparian soil samples was homogenized in $100 \mathrm{~mL}$ of sterile deionized water using a vortex. Tenfold dilution series were prepared from 1 $\mathrm{mL}$ of water samples and riparian soil and sediment suspensions. The cultures were incubated at $28^{\circ} \mathrm{C}$.
Fermenters, nitrate reducers, and sulfate reducers were cultured in anaerobic chambers.

The total aerobic heterotrophs and fermenters were cultured in plates with nutrient agar (plurypeptone, $5 \mathrm{~g} \mathrm{~L}^{-1}$; beef extract, $3 \mathrm{~g} \mathrm{~L}^{-1}$; $\mathrm{NaCl}, 8 \mathrm{~g} \mathrm{~L}^{-1}$; agar, $15 \mathrm{~g} \mathrm{~L}^{-1}$ ). After 2 days of incubation, the number of colony-forming units was counted (Lorch et al. 1995). The sulfate reducers' abundance were determined in $10 \mathrm{~mL}$ of specific liquid media $\left(\mathrm{NH}_{4} \mathrm{Cl}, 1 \mathrm{~g} \mathrm{~L}^{-1} ; \mathrm{K}_{2} \mathrm{HPO}_{4}, 0.5 \mathrm{~g} \mathrm{~L}^{-1} ; \mathrm{MgSO}_{4}, 2 \mathrm{~g} \mathrm{~L}{ }^{-1}\right.$; $\mathrm{Na}_{2} \mathrm{SO}_{4}, 0.5 \mathrm{~g} \mathrm{~L}^{-1} ; \mathrm{CaCl}_{2}, 0.1 \mathrm{~g} \mathrm{~L}^{-1}$; $\mathrm{Na}$ lactate $60 \%$, $6 \mathrm{~mL} \mathrm{~L}^{-1}$; and Fe). After 21 days of incubation, the formation of black FeS precipitate upon sulfide formation served as the indicator of sulfate reduction by the activity of sulfate reducers (Lorch et al. 1995). The nitrate-reducer microorganisms were cultured in tubes with Durham bells

Table 2 Chemical and physical characteristics of water, soil, and sediments of Suquía River study sites

\begin{tabular}{|c|c|c|c|}
\hline River sites & Water chemical characteristics & Sediment texture (\%) & Soil texture (\%) \\
\hline \multirow[t]{3}{*}{ RS, reference site (La Calera city) } & $\mathrm{pH}=7.05$ & Sand $=86.67$ & Sand $=67.83$ \\
\hline & Conductivity $=181.4 \mu \mathrm{S} \mathrm{cm} \mathrm{cm}^{-1}$ & Clay $=4.51$ & Clay $=4.86$ \\
\hline & Dissolved $\mathrm{O}_{2}=8.44 \mathrm{mg} \mathrm{L}^{-1}$ & Silt $=8.79$ & Silt $=27.32$ \\
\hline \multirow[t]{3}{*}{ S1, site 1 (Córdoba city west border) } & $\mathrm{pH}=7.23$ & Sand $=76.87$ & Sand $=46.67$ \\
\hline & Conductivity $=432.4 \mu \mathrm{S} \mathrm{cm}-1$ & Clay $=11.33$ & Clay $=6.34$ \\
\hline & Dissolved $\mathrm{O}_{2}=8.85 \mathrm{mg} \mathrm{L}^{-1}$ & Silt $=11.71$ & Silt $=46.99$ \\
\hline \multirow[t]{3}{*}{ S2, site 2 (Córdoba city down town) } & $\mathrm{pH}=7.26$ & Sand $=76.84$ & Sand $=46.99$ \\
\hline & Conductivity $=972.3 \mu \mathrm{S} \mathrm{cm}-1$ & Clay $=6.96$ & Clay $=11.68$ \\
\hline & Dissolved $\mathrm{O}_{2}=10.79 \mathrm{mg} \mathrm{L}^{-1}$ & Silt $=16.19$ & Silt $=41.34$ \\
\hline \multirow[t]{3}{*}{ S3, site 3 (Córdoba city east border) } & $\mathrm{pH}=7.33$ & Sand $=49.87$ & Sand $=26.64$ \\
\hline & Conductivity $=929.0 \mu \mathrm{S} \mathrm{cm} \mathrm{cm}^{-1}$ & Clay $=8.46$ & Clay $=24.05$ \\
\hline & Dissolved $\mathrm{O}_{2}=11.91 \mathrm{mg} \mathrm{L}^{-1}$ & Silt $=41.67$ & Silt $=49.32$ \\
\hline \multirow[t]{3}{*}{ S4, site 4 (Corazón de María village) } & $\mathrm{pH}=6.96$ & Sand $=75.57$ & Sand $=81.58$ \\
\hline & Conductivity $=952.3 \mu \mathrm{S} \mathrm{cm}-1$ & Clay $=6.0$ & Clay $=5.0$ \\
\hline & Dissolved $\mathrm{O}_{2}=4.07 \mathrm{mg} \mathrm{L}^{-1}$ & Silt $=18.43$ & Silt $=13.41$ \\
\hline \multirow[t]{3}{*}{ S5, site 5 (Río Primero city) } & $\mathrm{pH}=7.05$ & Sand $=77.34$ & Sand $=60.04$ \\
\hline & Conductivity $=785.0 \mu \mathrm{S} \mathrm{cm}-1$ & Clay $=5.13$ & Clay $=5.51$ \\
\hline & Dissolved $\mathrm{O}_{2}=5.74 \mathrm{mg} \mathrm{L}^{-1}$ & Silt $=17.53$ & Silt $=34.45$ \\
\hline
\end{tabular}


and $10 \mathrm{~mL}$ of specific liquid media (Na acetate, $10 \mathrm{~g} \mathrm{~L}^{-1}$; $\mathrm{KNO}_{3}, 20 \mathrm{~g} \mathrm{~L}^{-1} ; \mathrm{K}_{2} \mathrm{HPO}_{4}, 0.5 \mathrm{~g} \mathrm{~L}^{-1} ; \mathrm{MgSO}_{4}, 0.2 \mathrm{~g} \mathrm{~L}^{-1}$; $\mathrm{NaMoO}_{4} \cdot \mathrm{H}_{2} \mathrm{O}, 9 \times 10^{-4} \mathrm{~g} \mathrm{~L}^{-1} ; \mathrm{MnSO}_{4} \mathrm{H}_{2} \mathrm{O}, 0.02 \mathrm{~g} \mathrm{~L}^{-1}$; $\mathrm{H}_{3} \mathrm{BO}_{3} \mathrm{~m}, 0.028 \mathrm{~g} \mathrm{~L}^{-1}$; $\mathrm{CuSO}_{4} \cdot 5 \mathrm{H}_{2} \mathrm{O}, 8 \times 10^{-4} \mathrm{~g} \mathrm{~L}^{-1}$; and $\left.\mathrm{ZnSO}_{4} \cdot 7 \mathrm{H}_{2} \mathrm{O}, 2.2 \times 10^{-3} \mathrm{~g} \mathrm{~L}^{-1}\right)$. After 21 days of incubation, the nitrate reducers were detected by the formation of gas in Durham bells. The gas formation is due to the reduction of nitrate to $\mathrm{N}$ oxides and $\mathrm{N}_{2}$ (Lorch et al. 1995). Ammonifiers' abundance was determined in $5 \mathrm{~mL}$ of specific liquid media $\left(\mathrm{KH}_{2} \mathrm{PO}_{4}, 0.25 \mathrm{~g} \mathrm{~L}^{-1} ; \mathrm{MgSO}_{4} \cdot 7 \mathrm{H}_{2} \mathrm{O}\right.$, $0.125 \mathrm{~g} \mathrm{~L}^{-1}$; $\mathrm{NaCl}, 0.125 \mathrm{~g} \mathrm{~L}^{-1}$; CaCl. $2 \mathrm{H}_{2} \mathrm{O}, 0.0165 \mathrm{~g} \mathrm{~L}^{-1}$; $\mathrm{FeCl}_{3}, 3.36 \times 10^{-5} \mathrm{~g} \mathrm{~L}^{-1}$, EDTA-Na.2 $\mathrm{H}_{2} \mathrm{O} 1 \times 10^{-3} \mathrm{~g} \mathrm{~L}^{-1}$; $\mathrm{NaMoO}_{4} \cdot \mathrm{H}_{2} \mathrm{O}, 1.125 \times 10^{-4} \mathrm{~g} \mathrm{~L}^{-1} ; \mathrm{MnSO}_{4} \mathrm{H}_{2} \mathrm{O}, 2.53 \times$ $10^{-3} \mathrm{~g} \mathrm{~L}^{-1} ; \mathrm{H}_{3} \mathrm{BO}_{3}, 3.57 \times 10^{-3} \mathrm{~g} \mathrm{~L}^{-1}, \mathrm{CuSO}_{4} \cdot 5 \mathrm{H}_{2} \mathrm{O}, 1 \times$ $10^{-4} \mathrm{~g} \mathrm{~L}^{-1}$; $\mathrm{ZnSO}_{4} \cdot 7 \mathrm{H}_{2} \mathrm{O}, 2.75 \times 10^{-4} \mathrm{~g} \mathrm{~L}^{-1}$; and asparagine, $0.2 \mathrm{~g} \mathrm{~L}^{-1}$ ) incubated for 7 days. Then, ammonifiers' presence was detected by the formation of orange color with the aggregates of Nessler's reaction due to the presence of ammonia produced (Lorch et al. 1995). Cellulolytics' abundance was determined in $5 \mathrm{~mL}$ of specific liquid media $\left(\mathrm{K}_{2} \mathrm{HPO}_{4}, 1 \mathrm{~g} \mathrm{~L}^{-1} ; \mathrm{NaNO}_{3}, 0.5 \mathrm{~g} \mathrm{~L}^{-1} ; \mathrm{MgSO}_{4} \cdot 7 \mathrm{H}_{2} \mathrm{O}\right.$, $0.5 \mathrm{~g} \mathrm{~L}^{-1}$; $\mathrm{FeSO}_{4} \cdot 7 \mathrm{H}_{2} \mathrm{O}, 0.01 \mathrm{~g} \mathrm{~L}^{-1}$; and cellulose strips) incubated for 15 days. The presence of cellulolytics was detected by the alteration of cellulose strips as the consequence of cellulose degradation (Lorch et al. 1995). The abundance of microbial metabolic groups was expressed as $\log _{10}$ per gram of soil/sediment or milliliter of water $\left(\log \mathrm{g}^{-1}\right.$ or $\left.\mathrm{mL}^{-1}\right)$.

\section{Statistical analyses}

The differences of each parameter among sites, water flow periods, and habitat (water, sediment, and riparian soil) were analyzed using three-factor ANOVA (site, habitat, and period). The means were compared using the least significant difference (LSD) test $(p \leq 0.05)$.

\section{Results}

\section{Vegetation and organic matter fractions}

The vegetation structure was different among study sites. RS and S5 presented similar proportion of tree cover, while S2, S3, and S4 did not have trees. S4 had an elevated percentage of bare soil with some shrubs, whereas S3 did not present vegetation cover (Figure 2).

Soil HA, FA, and NHS content in both water flow periods, at S1 and S2 did not differ from RS, whereas the other sites were lower (Figure 3A,B). Soil OM fractions had few variations between flow periods at each study site. In high-flow period, the HA and NHS content increased at RS, while the other sites did not show these differences, except for $\mathrm{HA}$ in $\mathrm{S} 1, \mathrm{~S} 2$, and S4 (Figure 3A,B).

Sediment HA, FA, and NHS content in low-flow period was higher at S4, S2, and S3 than RS (Figure 4A). Conversely, in high-flow period, the same sites showed lower values than RS (Figure 4B). Similarly to soil, sediment HA, FA, and NHS content at RS increased in high-flow period, but at S2, S3, and S4, they showed an inverse pattern (Figure 4A,B).

\section{Abundance of microbial metabolic groups}

The total aerobic heterotrophs in low-flow period were higher at all study sites than RS in water, but in sediment at S2 and S4 only. The abundance of aerobic heterotrophs at RS and S1 was soil $>$ sediment $>$ water. However, this pattern was different at the rest of the sites (Figure 5A). In high-flow period the aerobic heterotrophs were lower at S2 and S3 than RS in sediment and at S3 in soil; contrarily in water, they were higher at S4 and S5. The pattern among habitats was soil $=$ sediment $>$ water $(p<0.05)$ (Figure 6A). In consequence, significant differences in aerobic heterotrophs abundance between high and low flows were detected only in water and sediment, and the variations depended on sites $(p<0.05)$ (Figure 7A). Accordingly, significant interactions among period $\times$ site, site $\times$ habitat, and period $\times$ site $\times$ habitat were detected.

The fermenters in low-flow period were higher at S5 and S4 than RS in water and at S4 and S2 in sediments only (Figure 5B). Similarly, in high-flow period they were higher at S4 and S5 than RS in water, but in sediment they did not differ, and in soil were higher at S2 and lower at S3 (Figure 6B). The pattern among habitats in both water flow periods was similar: soil $=$ sediment $>$ water (Figures 5B and 6B); however, fermenters in water and sediment showed significant increases in high-flow period at most sites (Figure 7B). In consequence, significant interactions among period $\times$ site, site $\times$ habitat, period $\times$ habitat, and period $\times$ site $\times$ habitat were detected.

The sulfate-reducer microorganisms in low-flow period were more abundant at all sites than RS in sediments and at S2, S4, and S5 in soil, while in water they were higher at S4 and lower at S3. Their abundance was not different among habitats at RS, whereas at S2 and S3 the pattern was soil $=$ sediment $>$ water (Figure $5 \mathrm{C}$ ). In high-flow period, the sulfate reducers were higher at S1, S2, and S3 than RS in water and at S1 and S5 in sediments; and the pattern at RS, S1, and S5 was soil = sediment $>$ water, while at S2, S3, and S4 was soil > sediment $>$ water (Figure 6C). In addition, the sulfate reducers presented differences between periods in the three habitats (Figure 7C). Therefore, significant interactions among period $\times$ site, site $\times$ habitat, period $\times$ habitat, and period $\times$ site $\times$ habitat were detected.

The nitrate-reducer microorganisms in low-flow period showed higher abundance at S2, S4, and S5 than RS in soil, water, and sediment, and at S3 in sediments too (Figure 5D). In high-flow period the nitrate reducers at all sites were higher than RS in water. However, they were lower at S2 and S3 in sediments and at S4 in soil. In both low- and high-flow periods at all sites, the pattern among habitats 


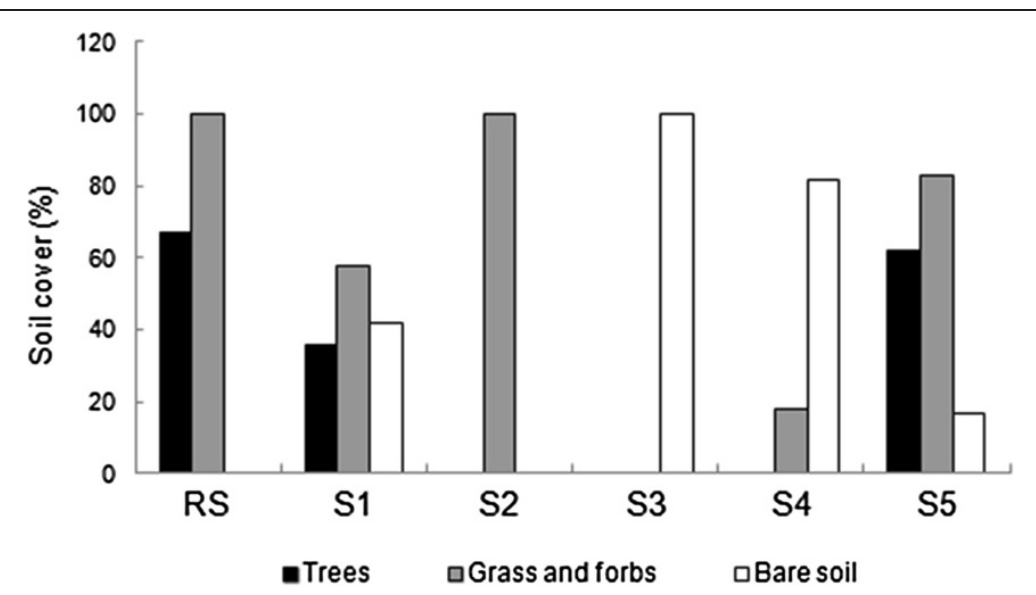

Figure 2 Soil cover (\%) at Suquía River study sites. RS, reference site; S1, site 1; S2, site 2; S3, site 3; S4, site 4; and S5, site 5.
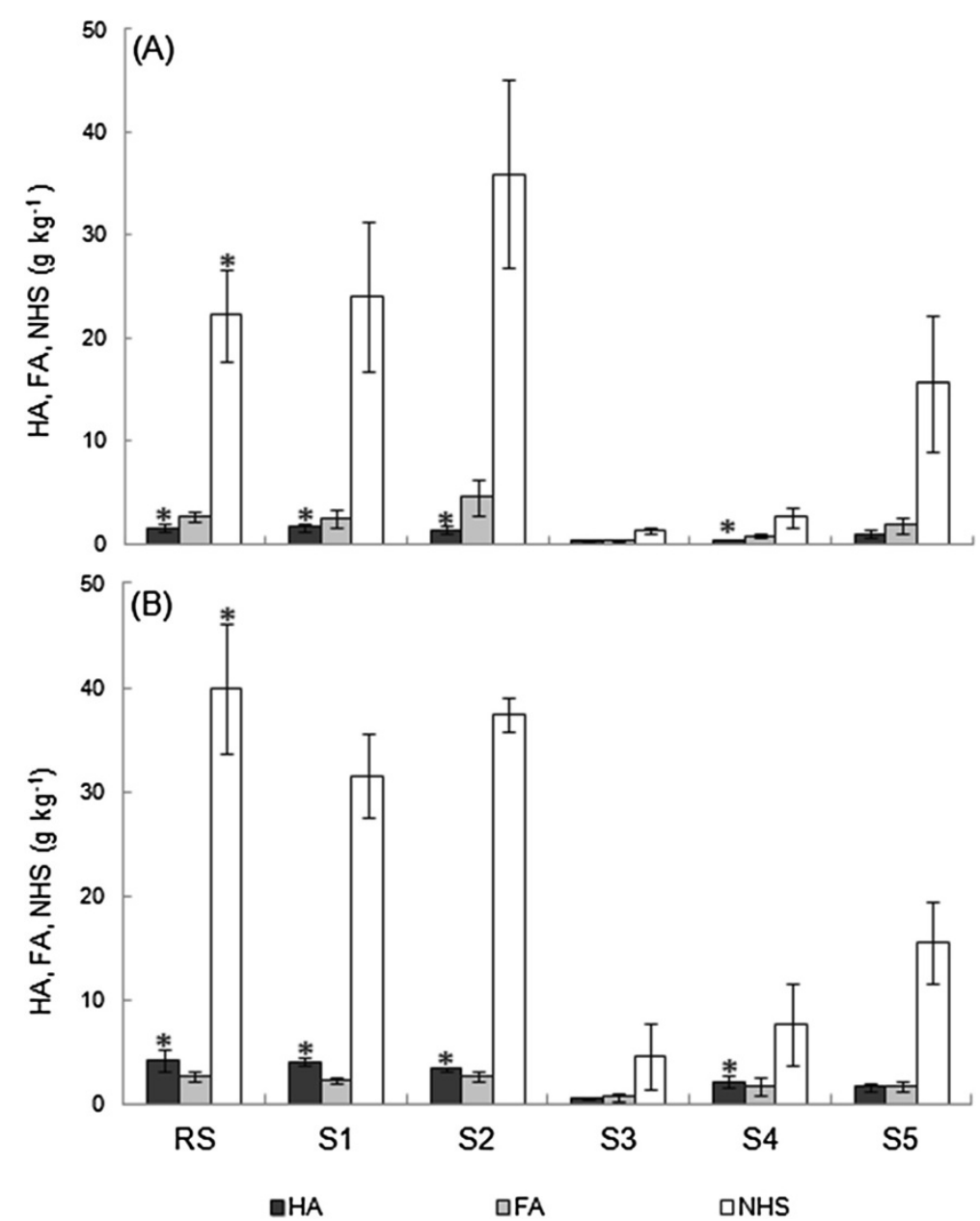

Figure 3 Riparian soil organic matter fractions. Riparian soil organic matter fractions $\left(\mathrm{g} \mathrm{kg}^{-1}\right)$ at Suquía River study sites during (A) low- and (B) high-flow periods. Asterisk indicates significant differences between flow periods for each study site (LSD test $p>0.05$ ). RS, reference site; $\mathrm{S1}$, site 1; S2, site 2; S3, site 3; S4, site 4; and S5, site 5. FA, fulvic acids; HA, humic acids; NHS, non-humic substances. Bars indicate SE. 

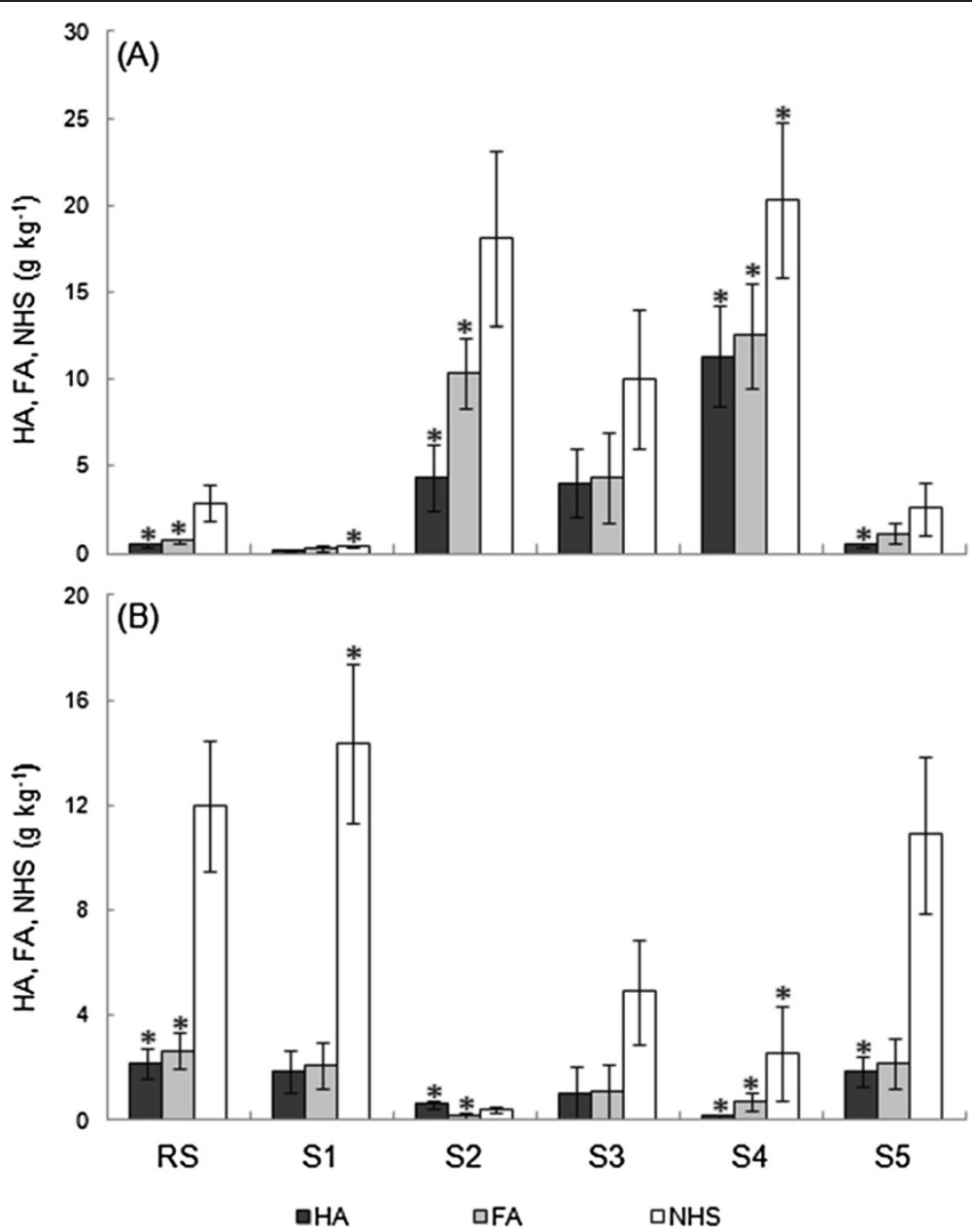

Figure 4 Sediment organic matter fractions. Sediment organic matter fractions $\left(\mathrm{g} \mathrm{kg}^{-1}\right)$ at Suquía River study sites during (A) low- and (B) high-flow periods. Asterisk indicates significant differences between flow periods for each study site (LSD test $p>0.05$ ). RS, reference site; S1, site 1; S2, site 2; S3, site 3; S4, site 4; and S5, site 5. FA, fulvic acids; HA, humic acids; NHS, non-humic substances. Bars indicate SE.

was soil = sediment $>$ water, except at S3 in high-flow period (Figures $5 \mathrm{D}$ and $6 \mathrm{D}$ ). The nitrate reducers presented differences between flow periods in sediment and water only, increasing or decreasing according to sites (Figure 7D). The nitrate reducers also showed significant interactions among period $\times$ site, site $\times$ habitat, period $\times$ habitat, and period $\times$ site $\times$ habitat.

The ammonifiers were the most abundant group in both high- and low-flow periods (water, $36.88 \log \mathrm{mL}^{-1}$; sediment, $14.21 \log \mathrm{g}^{-1}$; and soil, $\left.17.80 \log \mathrm{g}^{-1}\right)$. In both periods, they were higher at all sites than RS in soil and water, except at S1 in water in high-flow period (Figures $5 \mathrm{E}$ and $6 \mathrm{E})$. In sediments, ammonifiers showed higher abundance at S4 and S5 than RS in low-flow period and at S3 and S4 in high-flow period. In contrast with the other microbial metabolic groups, the highest abundance of ammonifiers was detected in water (Figures $5 \mathrm{E}$ and $6 \mathrm{E}$ ). The ammonifiers presented differences between flow periods in all habitats with increases in high-flow period
(Figure 7E). Also, ammonifiers presented the following significant interactions: site $\times$ habitat, period $\times$ habitat, and period $\times$ site $\times$ habitat.

The cellulolytics in low-flow period was higher than RS at S2, S3, S4, and S5 in sediments only (Figure 5F). In contrast, in high flow, they were lower at S5 in water and at S3 in soil (Figure 6F). The differences of cellulolytics among habitat were scarce in both low- and high-flow periods with a hieratic pattern (Figures $5 \mathrm{~F}$ and $6 \mathrm{~F}$ ). Contrarily to the other metabolic microbial groups, cellulolytics decreased in almost all sites in high-flow period (Figure 7F), and they did not present significant interactions among situations.

\section{Reference site characteristics}

The results observed at RS agree with the characteristics of lotic ecosystems minimally disturbed (Wetzel 2001):

(a) vegetation cover with a mix of trees and grass-forbs,

(b) soil OM (3.6\%) with 15\% of HS similar in both periods, 


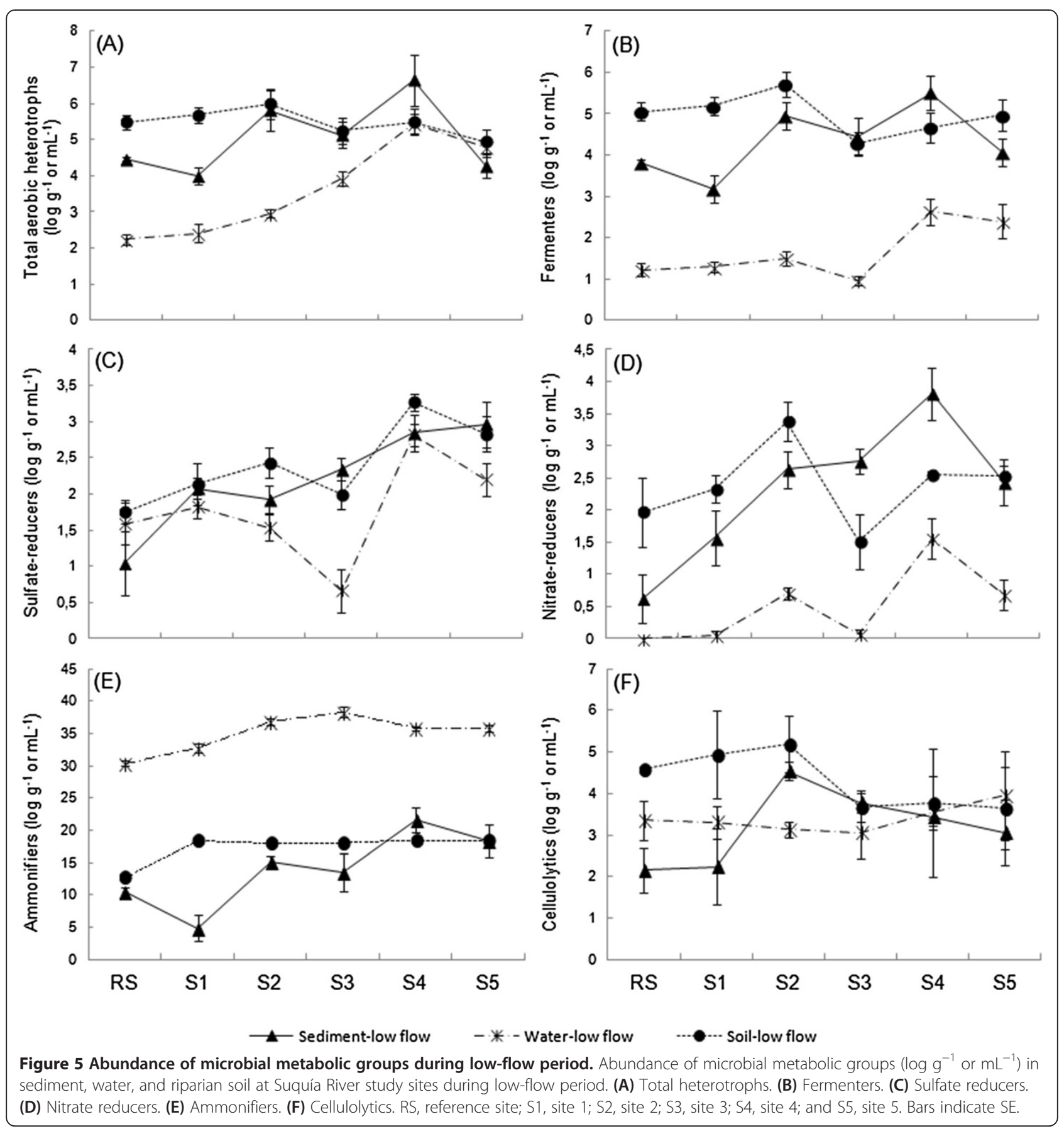

(c) sediment OM (10\%) with $29 \%$ of HS similar in both periods also, (d) higher abundance of total microorganisms in water than soil (40.2\%) and sediments (16.6\%), (e) higher proportion of anaerobic microorganisms in soil and sediments $(27.8 \%$ and $25.8 \%$ respectively) than water (6.9\%), (f) ammonifier as dominant group in all habitats (water, 76.2\%; sediments, 40.9\%; soil, 37.9\%) and nitratereducer as the most scarce group (water, $0.15 \%$; sediments, $5.03 \%$; soil, 6.75\%), (g) increases in high-flow period of almost all microbial groups in the three habitats, and (h) increases in high-flow period of sediment OM and HS content and soil NHS.

\section{Discussion}

Our results showed that all analyzed study sites of Suquía River middle-low basin differed in their characteristics of water self-depuration capacity with respect to RS (minimally disturbed). Considering that all climatic characteristics and flow variation are the same for all study sites, the differences detected depend on the 


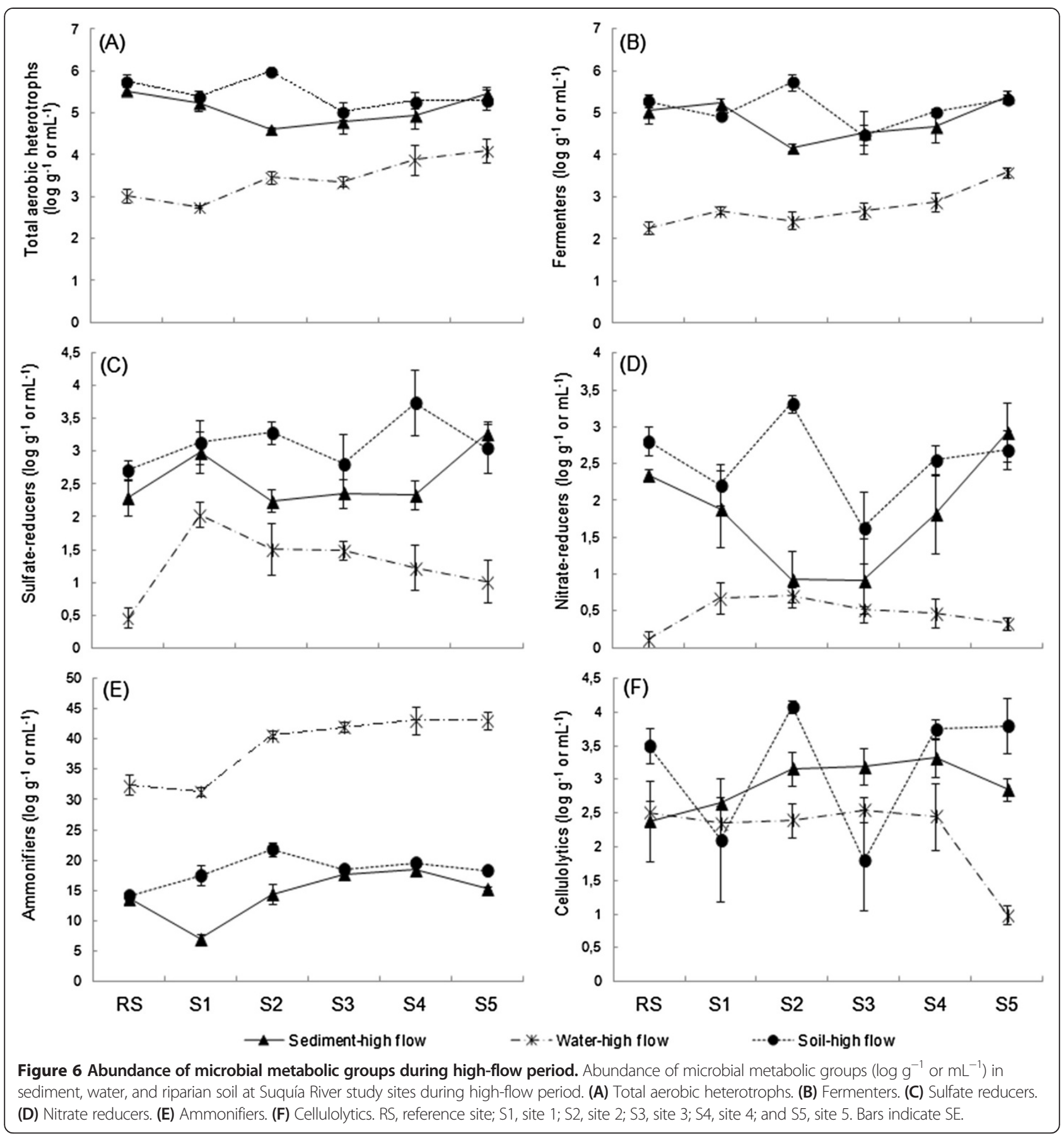

combination of multiple factors, some of natural origin and some anthropogenic.

The dynamics of microbial metabolic groups at RS agree with numerous studies which indicate that part of the degradation is carried out quickly in the water by aerobic microorganisms and the other in soil and sediment with a predominance of anaerobic bacteria (Wetzel 2001; Dzyuban 2003; Dzyuban 2005; Amalfitano et al. 2008). The ammonifiers were the most abundant group, probably due to the high physiologic variability of these microorganisms and that ammonifying activity has few limitations and only depends on the availability of $\mathrm{N}$ organic compounds (Paul 2007). The strong dominance of ammonifiers is probably due to the type of allochthonous $\mathrm{OM}$ that the river receives. The Suquía River does not receive much litter from riparian vegetation; therefore, most allochthonous OM comes from San Roque Dam in which the water is highly eutrophicated with an elevated algal density (Amé et al. 2003). It is widely known that algae have a low $\mathrm{C} / \mathrm{N}$ ratio which may explain the 


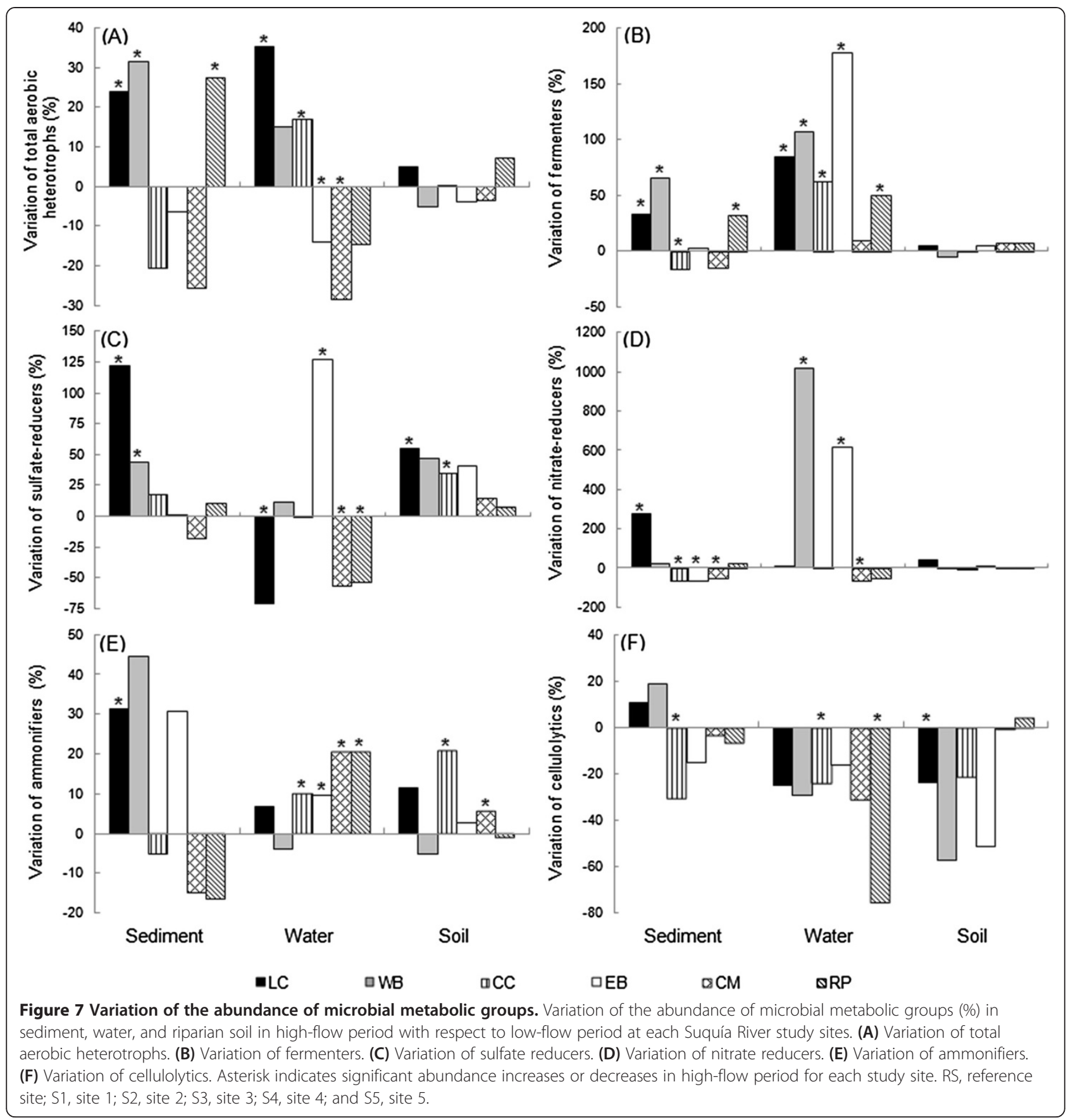

ammonifiers' dominance (Wetzel 2001). By contrast, the low abundance of nitrate-reducer in Suquía River has been observed by Reyna et al. (2010), suggesting a strong competition with plants, algae, and other microorganisms for nitrate (Wetzel 2001).

The increases of sediment and soil OM fractions at RS in high-flow period would reflect major deposition and retention due to the high $\mathrm{OM}$ residues transported by water in this period (Wetzel 2001). This increase of OM plus the warm-rainy conditions justify the higher abundance of all microbial groups during high flow period.

\section{Factors affecting the characteristics of water self-depuration capacity \\ Effect of stream bank and bed geomorphology}

Our results suggest that the geomorphology of the stream bank and bed is an important influential natural factor on water self-depuration characteristics of Suquía River due to the differences in soil and sediments textures. The 
Suquía River middle basin presents fluvial terraces with erosion-deposition cycles; therefore, the stream bank and bed have a variable texture depending on the degree of erosion and water flow in geologic times (Gordillo and Lencinas 1979). The hard stream bank with fine and compacted particles (toph) such as the soil of S3 is scarcely erodible and increases water speed. In consequence, the water self-depuration characteristics are reduced with respect to RS (particularly vegetation and soil OM). It is well known that toph soils do not allow the vegetation to grow and the highest water speed prevents OM deposition, eliminating the possibility of nutrients uptake and retention of xenobiotics (Parkyn et al. 2003; McIntyre et al. 2009; Sahu and Gu 2009). Most importantly, though, root plants are known to provide a source of available $C$ to microorganisms (Gift et al. 2010).

The effect of soil and sediments' heterogeneity on microbial community has been reported by numerous authors (Prosser and Embley 2002; Koschorreck and Darwich 2003; Leloup et al. 2005). The fact that at S3 (a) sediments $\mathrm{OM}$ and $\mathrm{HS}$ are higher than RS (increases, 24\% and $73 \%$ respectively), (b) there is no vegetation cover, and (c) the relative abundance of soil degrading microbial metabolic groups is similar to RS, which would indicate that the inorganic and organic compounds come from water and not from stream-bank soil. On the other hand, S4 presented the highest proportion of coarse granulometry and lesser organic matter content (79\%) in riparian soil, scarce vegetation, and different patterns of microbial abundance in all habitats, compared to RS. We consider that the differences in microbial abundance are caused by the high water pollution at S4 site.

\section{Effect of urban discharges}

The urban discharges strongly modify the characteristics of water self-depuration compared to RS, particularly downstream WWTP. Urban discharges affect OM and HS in sediments (range $124 \%$ to $306 \%$ ), increasing the abundance of all microbial metabolic groups in water and sediments (33\% and 37\% respectively), mainly composed of anaerobic groups in water (53\%) like sulfate reducers (36\%). The additional amount of OM from WWTP elevates the microbial activity, producing anaerobic conditions that favor sulfate reduction (Leonov and Chicherina 2008). Similar results have been obtained by Kosolapov et al. (2003) who found major sulfate reducers' activity in water and sediments near to sewage discharges. Moreover, Leonov and Chicherina (2008) affirm that this process is more important in shallow waters, which agrees with the characteristics of Suquía River. In this regard, Dzyuban (2005) reported a higher abundance of fermenters in sediments of Sheksna River in Russia associated with the continuous input of organic residues.
It should be highlighted that the impact of urban discharges on anaerobic microbial community of soil and sediments is detected in all urban sites, although in different proportions. These differences are probably due to the proximity to sources; for example, the highest abundance of total anaerobic bacteria, and particularly the sulfate-reducer group, was found in sediments at S1 respect to RS (36\% and $85 \%$ respectively), even higher than S4 (13\% and 36\%). This could be because S1 is near to neighborhoods with small sewage discharges, while, although $\mathrm{S} 4$ received a greater sewage discharges, it is located $12 \mathrm{~km}$ downstream WWTP.

Pasquini et al. (2012) showed that the sulfate concentration in Suquía River water increases downstream of Córdoba city. Therefore, in downstream Córdoba city sites, the higher organic C (Merlo et al. 2011) and sulfate concentrations in water and the low dissolved $\mathrm{O}_{2}$ concentration favor the development of sulfate reducers (Leloup et al. 2005; Leonov and Chicherina 2008). Sulfate reducers have been scarcely studied in lotic ecosystems. However, although sulfate reducers are less abundant in freshwater, numerous authors agree that sulfate reducers' activity has a key role not only in $\mathrm{C}$ and $\mathrm{S}$ cycles but also in anaerobic degradation of organic contaminants in polluted ecosystems (Dhillon et al. 2003; Pérez-Jiménez and Kerkhof 2005; Leonov and Chicherina 2008).

Due to the great nitrate contamination that supports aquatic ecosystems and particularly Suquía River (Reyna et al. 2010; Merlo et al. 2011), nitrate-reducer communities have been studied in diverse environments for their capacity to remove this nutrient from ecosystems (Perryman et al. 2008; Gift et al. 2010). Our results did not show a substantial increase of nitrate-reducer bacteria in sediments due to the high water pollution (range 3\% to 14\%), as the reported by Reyna et al. (2010) for the same sector of Suquía River. Unfortunately, these data are poorly comparable because we analyzed the abundance of cultivable nitrate reducers, while Reyna et al. (2010) measured the copies of the narG gene of one new genus by real-time PCR. On the other hand, riparian zones are important in river water self-depuration; in this sense, the nitrate reducers showed major abundance in soils with the highest nitrate concentrations reported by Merlo et al. (2011).

\section{Effect of stream channelization}

It is widely known that the stream channelized with cement reduces the water self-depuration characteristics due to (a) the scarce deposition of sediments by higher velocity of water in the impervious surface (Huang et al. 2009) and (b) the lack of contact of water with riparian vegetation (Elmore and Kaushal 2008). However, in the site where Suquía River is channelized (S2), the channel has many destroyed areas through in which high-flow 
period, areas of waterlogging occur and they drain very slowly when the level of water decreases. These waterlogged areas justify the high soil and sediment OM and HS values obtained and the $100 \%$ grass and forbs cover. Moreover, the high increase of sediment cellulolytic microorganisms at S2 (47\%) could be associated with the degradation of grass residues due to frequent cutting based on aesthetic consideration. Diverse cellulolytic species have the capacity to produce celulolase enzymes in aerobic and anaerobic conditions (Kumar et al. 2008). It was informed that cellulose global degradation occurs in aerobic conditions in $90 \%$ and in anaerobic conditions in $10 \%$ (Wei et al. 2009; Ransom-Jones et al. 2012). The fact that in this work cellulolytic microorganisms were detected in both aerobic and anaerobic environments indicates that the degradation of cellulose occurs in both conditions.

\section{Effect of flow variations}

The literature mentions the double paradox criteria of the rivers due to hydrologic episodes: periods of sediment deposition vs. sediment remobilization (Seibert et al. 2009). We observed increases of all sediment OM fractions and soil labile OM during high-flow period in RS, indicating that it is the period of greatest deposition probably due to the major OM particulate input from vegetation residues falling into streams (Kochi et al. 2010). Conversely, study sites' downstream anthropogenic sources present a reversed pattern: more sediment deposition during low-flow period. One possible explanation is that during low-flow period, the river receives input from discharges with elevated OM content, which are deposited on stream bed due to the low water velocity. On the other hand, high flow causes dilution of pollutants of discharges as reported by Merlo et al. (2011) and Pasquini et al. (2012), and the major water velocity favors the drag of OM deposited during low-flow period.

The significant interactions detected (date $\times$ site $\times$ habitat) for almost all microbial metabolic groups indicate a differential response to water flow change. Similar to RS, almost all microbial groups increase during high-flow period in water of all study sites, which could be related with the major temperature of this period. However, the abundance of nitrate reducers in sediments decreases (52\% to $67 \%$ ) during high-flow period at the most polluted sites (S2, S3, and S4). This is probably due to the rise of dissolved $\mathrm{O}_{2}$ concentration by water velocity (Oehler et al. 2009) and the lower nitrate content in sediment as reported by Merlo et al. (2011) during high-flow period. Similarly, the lower abundance of sulfate reducers in the water of some sites during high-flow period could be probably due to the dilution of sulfate as informed by Pasquini et al. (2012), the decreasing of organic C (Merlo et al. 2011), and the rise in dissolved $\mathrm{O}_{2}$ concentration.

\section{Conclusions}

Based on the results of this study case, we reach two conclusions: (1) the Suquía River middle-low basin has great heterogeneity of water self-depuration characteristics, and (2) although some river sectors present good characteristics of water self-depuration, the river does not appear to overcome the anthropogenic impact produced by Córdoba city downstream at $50 \mathrm{~km}$ (Merlo et al. 2011).

Therefore, restoration programs for polluted rivers should be planned according to each sector for natural and anthropic characteristics and supplemented with strict controls of quality and volume of effluent discharges. We consider that key actions for restoration programs are the following: (a) the elimination of impervious surface and forestation of stream banks to favor the positive vegetation effects on water decontamination (Huang et al. 2009; Oehler et al. 2009); (b) the building of artificial wetlands to improve the uptake and retention of xenobiotics and the volatilization of nutrients (Hunter et al. 2009), particularly upstream sites where the characteristics of water self-depuration are very reduced; and (c) the removing of sediments and re-meandering the river course where sewage sediments present great accumulation (Dzyuban 2003). We hope that these findings may be applicable to many other polluted rivers with similar geomorphologic and hydrological characteristics.

\section{Competing interests}

The authors declare that they have no competing interests.

\section{Authors' contributions}

$\mathrm{CM}$ and $\mathrm{AA}$ designed the methodology, collected the samples and drafted the manuscript. CM analyzed the samples and performed the statistical analyses. All authors read and approved the final manuscript.

\section{Acknowledgments}

Financial support was provided by the Agencia Nacional de Promoción Científica y Tecnológica (PICTO UNC 36026) and fellowship of Carolina Merlo by FONCyT (Agencia Nacional de Promoción Científica y Tecnológica) and CONICET (Consejo Nacional de Investigaciones Científicas y Técnicas).

Received: 24 April 2013 Accepted: 23 June 2014

Published online: 03 September 2014

\section{References}

Abril A, Merlo C, Noe L (2013) Realistic soil C sink estimate in dry forests of western Argentina based on humic substance content. J Arid Environ 91:113-118

Amalfitano S, Fazi S, Zoppini A, Caracciolo AB, Grenni P, Puddu A (2008) Responses of benthic bacteria to experimental drying in sediments from Mediterranean temporary rivers. Microb Ecol 55:270-279

Amé MV, Díaz MD, Wunderlin DA (2003) Occurrence of toxic cyanobacterial blooms in San Roque Reservoir (Córdoba, Argentina): a field and chemometric study. Environ Toxicol 18:192-201

Artigas J, Romaní AM, Gaudes A, Muñoz I, Sabater S (2009) Organic matter availability structures microbial biomass and activity in a Mediterranean stream. Freshwater Biol 54:2025-2036

Barton LL, Northup DE (2011) Microbial ecology. Wiley-Blackwell, New Jersey Calace N, Deriu D, Petronio BM, Pietroletti M (2009) Adsorption isotherms and breakthrough curves to study how humic acids influence heavy metal-soil interactions. Water Air Soil Poll 204:373-383 
Carey RO, Migliaccio KW (2009) Contribution of wastewater treatment plant effluents to nutrient dynamics in aquatic systems: a review. Environ Manage 44:205-217

Contardo-Jara V, Galanti LN, Amé MV, Monferrán MV, Wunderlin DA, Wiegand C (2009) Biotransformation and antioxidant enzymes of Limnoperna fortunei detect site impact in watercourses of Córdoba, Argentina. Ecotoxicol Environ Saf 72:1871-1880

Daya I (1987) Variación de la comunidad de diatomeas del Río Suquía y La Cañada. Tesis Doctoral. Facultad de Ciencias Exactas, Físicas y Naturales, Universidad Nacional de Córdoba, Córdoba, Argentina

Dhillon A, Teske A, Dillon J, Stahl DA, Sogin ML (2003) Molecular characterization of sulfate-reducing bacteria in the Guaymas Basin. Appl Environ Microbiol 69:2765-2772

Dzyuban AN (2003) Bacteriobenthos of the upper Volga Reservoirs as a characteristic of their environmental state. Water Resour 30:680-688

Dzyuban AN (2005) The environmental conditions of the Shesna Reservoir: assessment based on microbiological investigations. Water Resour 32:65-72

Elmore AJ, Kaushal SS (2008) Disappearing headwaters: patterns of stream burial due to urbanization. Front Ecol Environ 6:308-312

Feral CJW, Epstein HE, Otter L, Aranibar JN, Shugart HH, Macko SA, Ramontsho J (2003) Carbon and nitrogen in the soil-plant system along rainfall and land-use gradient in southern Africa. J Arid Environ 54:327-343

Gift DM, Groffman PM, Kaushal SS, Mayer PM (2010) Denitrification potential, root biomass, and organic matter in degraded and restored urban riparian zones. Restor Ecol 18:113-120

Gordillo CE, Lencinas AN (1979) Sierras Pampeanas de Córdoba y San Luis. In: Geología Regional Argentina. Academia Nacional de Ciencias, Córdoba, Argentina

Groffman PM, Butterbach-Bahl K, Fulweiler RW, Gold AJ, Morse JL, Stander EK, Tague C, Tonitto C, Vidon P (2009) Challenges to incorporating spatially and temporally explicit phenomena (hotspots and hot moments) in denitrification models. Biogeochemistry 93:49-77

Haro JG, Gutierrez M, Bistoni MA, Bertolio WR, Lopez AE (1986) Ictiofauna del Rio Primero (Suquía) (Córdoba, Argentina). Hist Nat 6:53-63

Huang JC, Mitsch WJ, Zhang L (2009) Ecological restoration design of a stream on a college campus in central Ohio. Ecol Eng 35:329-340

Hunter RG, Day JW, Lane RR, Lindsey J, Day JN, Hunter MG (2009) Impacts of secondarily treated municipal effluent on a freshwater forested wetland after 60 years of discharge. Wetlands 29:363-371

Kang S, Lin H (2009) General soil-landscape distribution patterns in buffer zones of different order streams. Geoderma 151:233-240

Kochi K, Mishima Y, Nagasaka A (2010) Lateral input of particulate organic matter from bank slopes surpasses direct litter fall in the uppermost reaches of a headwater stream in Hokkaido, Japan. Limnology 11:77-84

Koschorreck M, Darwich A (2003) Nitrogen dynamics in seasonally flooded soils in the Amazon floodplain. Wetlands Ecol Manage 11:317-330

Kosolapov DB, Rogozin DY, Gladchenko IA, Kopylov Al, Zakharova EE (2003) Microbial sulfate reduction in a brackish meromictic steppe lake. Aquat Ecol 37:215-226

Kumar R, Singh S, Singh OV (2008) Bioconversion of lignocellulosic biomass: biochemical and molecular perspectives. J Ind Microbiol Biotechnol 35:377-391

Leloup J, Petit F, Boust D, Deloffre J, Bally G, Clarisse O, Quillet L (2005) Dynamics of sulphate-reducing microorganisms (dsrAB genes) in two contrasting mudflats of the Seine Estuary (France). Microb Ecol 50:307-314

Leonov AV, Chicherina OV (2008) Sulfate reduction in natural water bodies: 1. The effect of environmental factors and the measured rates of the process. Water Resour 35:417-434

Lopez MJ, Vargas-Garcia MDC, Suárez-Estrella F, Moreno J (2006) Biodelignification and humification of horticultural plant residues by fungi. Int Biodeter Biodegr 57:24-30

Lorch HJ, Benckiser G, Ottow JC (1995) Basic methods for counting microorganisms in soil and water. In: Alef K, Nannipieri P (ed) Methods in applied soil microbiology and biochemistry. Academic, London

Maggioni T, Hued AC, Monferrán MV, Bonansea Rl, Galanti NL, Amé MV (2012) Bioindicators and biomarkers of environmental pollution in the middle-lower basin of the Suquía River (Córdoba, Argentina). Arch Environ Contam Toxicol 63:337-353

Mangeaud A (1998) Macroinvertebrados bentónicos como bioindicadores de la calidad del agua en la cuenca del Suquía (Córdoba, Argentina): Tesis Doctoral. Facultad de Ciencias Exactas Físicas y Naturales. Universidad Nacional de Córdoba, Córdoba, Argentina

Marinari S, Dell'Abate MT, Brunetti G, Dais C (2010) Differences of stabilized organic carbon fraction and microbiological activity along Mediterranean Vertisols and Alfisols profiles. Geoderma 156:379-388
McIntyre RE, Adams MA, Ford DJ, Grierson PF (2009) Rewetting and litter addition influence mineralisation and microbial communities in soils from a semi-arid intermittent stream. Soil Biol Biochem 41:92-101

Merlo C, Abril A, Amé MV, Argüello GA, Carreras HA, Chiappero MS, Hued AC, Wannaz E, Galanti LN, Monferrán MV, González CM, Solís VM (2011) Integral assessment of pollution in the Suquía River (Córdoba, Argentina) as a contribution to lotic ecosystem restoration programs. Sci Total Environ 409:5034-5045

Monferrán MV, Galanti LN, Bonansea Rl, Amé MV, Wunderlin DA (2011) Integrated survey of water pollution in the Suquía River basin (Córdoba, Argentina). J Environ Monit 13:398-409

Nelson DW, Sommers LE (1996) Total carbon, organic carbon, and organic matter. In: Sparks DL, Page AL, Helmke PA, Loeppert RH, Soltanpour PN, Tabatabai MA, Johnston CT, Sumner ME (ed) Methods of soil analysis III. Chemical methods. Soil Science Society of America, American Society of Agronomy, Madison

Nishihama S, Haraguchi A, Kawano T, Michiki K, Nakazawa K, Suzuki T, Uezu K, Yoshizuka K (2008) Seasonal changes in the microbial population of the water column and sediments of the Ongagawa River, northern Kyushu, Japan. Limnology 9:35-45

Oehler F, Durand P, Bordenave P, Saadi Z, Salmon-Monviola J (2009) Modelling denitrification at the catchment scale. Sci Total Environ 407:1726-1737

Parkyn SM, Davies-Colley RJ, Halliday NJ, Costley KJ, Croker GF (2003) Planted riparian buffer zones in New Zealand: do they live up to expectations? Restor Ecol 11:436-447

Pasquini Al, Formica SM, Sacchi GA (2012) Hydrochemistry and nutrients dynamic in the Suquía River urban catchment's Córdoba, Argentina. Environ Earth Sci 65:453-467

Paul E (ed) (2007) Soil microbiology, ecology and biochemistry. Academic, San Diego

Pérez-Jiménez JR, Kerkhof $\amalg$ (2005) Phylogeography of sulphate-reducing bacteria among disturbed sediments disclosed by analysis of the dissimilatory sulfite reductase genes (dsrAB). Appl Environ Microbiol 71:1004-1011

Perryman SE, Rees GN, Walsh CJ (2008) Analysis of denitrifying communities in streams from an urban and non-urban catchment. Aquat Ecol 42:95-101

Perryman SE, Rees GN, Walsh CJ, Grace MR (2011) Urban stormwater runof drives denitrifying community composition through changes in sediment texture and carbon content. Microb Ecol 61:932-940

Pesce SF, Wunderlin DA (2000) Use of water quality indices to verify the impact of Córdoba city (Argentina) on Suquía River. Water Res 34:2915-2926

Prosser Jl, Embley TM (2002) Cultivation-based and molecular approaches to characterization of terrestrial and aquatic nitrifiers. Antonie Van Leeuwenhoek $81: 165-179$

Ransom-Jones E, Jones DL, McCarthy AJ, McDonald JE (2012) The Fibrobacteres: an important phylum of cellulose-degrading bacteria. Microb Ecol 63:267-281

Reyna L, Wunderlin DA, Genti-Raimondi S (2010) Identification and quantification of a novel nitrate-reducing community in sediments of Suquía River along a nitrate gradient. Environ Pollut 158:1608-1614

Sahu M, Gu RR (2009) Modeling the effects of riparian buffer zone and contour strips on stream water quality. Ecol Eng 35:1167-1177

Seibert J, Grabs T, Köhler S, Laudon H, Winterdahl M, Bishop K (2009) Linking soiland stream-water chemistry based on a riparian flow - concentration integration model. Hydrol Earth Syst Sci 13:2287-2297

Wallis E, Nally RM, Lake S (2009) Do tributaries affect loads and fluxes of particulate organic matter, inorganic sediment and wood? Patterns in an upland river basin in south-eastern Australia. Hydrobiologia 636:307-317

Wei H, Xu Q, Taylor LE, II, Baker JO, Tucker MP, Ding SY (2009) Natural paradigms of plant cell wall degradation. Curr Opin Biotechnol 20:330-338

Wetzel RG (ed) (2001) Limnology. Lake and river ecosystems, 3rd edition. Academic, San Diego

Wunderlin D, Díaz M, Amé MV, Pesce S, Hued A, Bistoni MA (2001) Pattern recognition techniques for the evaluation of spatial and temporal variations in water quality. A case study: Suquía river basin (Córdoba, Argentina). Water Res 35:2881-2894

\section{doi:10.1186/s40693-014-0012-4}

Cite this article as: Merlo and Abril: Multidisciplinary approach to assess the water self-depuration characteristics of Suquía River (Córdoba, Argentina). Revista Chilena de Historia Natural 2014 87:12. 